\title{
FEATURES OF THE USE OF ALTERNATIVE ENERGY SOURCES IN UKRAINE AND THE WORLD
}

\author{
Olena LIUTAK ${ }^{1}$, Larysa SAVOSH ${ }^{2}$, Olena BAULA ${ }^{3}$ \\ Lutsk National Technical University, Ukraine
}

\begin{abstract}
The purpose of the work is to consider the theoretical applied foundations of the use of alternative sources of energy in Ukraine and the world, the study of the theoretical bases, and specificity of the use of existing alternative energy sources in the context of globalization, the world practice of the use of alternative sources of energy; lighted up the features of the use of alternative energy sources in Ukraine in modern conditions. A special attention is focused on the analysis of energy efficiency of Ukrainian regions and its determinants, and investigated the general trend regarding the situation in the oil market and investment in renewable energy. Methodology The study is based on the indicators of renewable energy and energy efficiency of the regions of Ukraine in 2015 and the inclusion of indicators of the average oil price, investment in renewable energy sources, the rate of growth of prices, growth rates of investments in 2004-2016. In general, in mainland Ukraine, there are several dozens of solar power plants capacity from 1 to $15 \mathrm{MW}$, and more than a dozen SES have a capacity from 20 to $120 \mathrm{MW}$ (some under construction). Thanks to a special "green tariff", which is valid since 2011, solar energy has become a lucrative business that has attracted foreign investors. According to statistics, the volume of commissioning of new solar power plants in 2013 almost doubled compared to 2012. Results. It is determined that an important element of policy implementation in the field of energy saving and use of alternative sources is the introduction of financial, organizational and economic activities that give the opportunity to implement principles of sustainable development in public administration, and in terms of decentralization - by local governments. In the management, the determining are such policies in the field of energy efficiency as: pricing mechanisms; mechanisms of regulation and control; financial measures and fiscal incentives; mechanisms of development and transformation of the market; technological development; business development and capacity building (creation of energy service companies (ESCOs); the curriculum; the development of industry of energy efficiency); financial recovery.
\end{abstract}

Key words: alternative sources of energy, renewable energy, energy, energy security, green fare, energy efficiency.

JEL Classification: O44, E01, P25

\section{Introduction}

The development and use of alternative and renewable sources of energy is an important factor to enhance energy security and reduce the negative anthropogenic impact on the environment.

The importance of studying the development of alternative energy is obvious because it plays a crucial role in reducing greenhouse emissions, reducing the negative impact on the environment, increases energy security, helps to reduce the dependence on energy imports.

Alternative energy, built on the use of inexhaustible energy sources, can become a "key" that will open the door to independence in the gas and fuel sectors. If the twentieth-century scientists call "oil" one, the twenty-first century can really be an era of renewable energy. Ukraine has large reserves of almost all types of alternative energy, thus it may become one of the most developed independent countries from exporters in the future. To the problem of renewable energy are devoted the works of such leading scholars as: S. P. Denysiuk, V. A. Zhovtiansky, D. V. Zerkalov, A. M. Liashenko, V. M. Oleiko. Among the works of the foreign researchers, scientifically and practically interest have the works of D. Boyls, John. Tweidel, S. Zakolei, H. A. Atamanchuk, B. Horieva, P. Smith, P. Thompson, H. Scheer, and others.

The main purpose of this article is to study peculiarities of using alternative sources of energy in Ukraine and the world, to determine the theoretical basis and the specific

\footnotetext{
Corresponding author:

${ }^{1}$ Department of International Economic Relations, Lutsk National Technical University.

E-mail: olenalutak@gmail.com

${ }^{2}$ Department of International Economic Relations, Lutsk National Technical University.

E-mail: larysa.savosh9@gmail.com

${ }^{3}$ Department of International Economic Relations, Lutsk National Technical University.

E-mail: o.baula@lntu.edu.ua
} 
use of existing sources of alternative energy in the context of globalization, the global practice of using alternative sources of energy, lighting, the use of alternative energy sources in Ukraine in modern conditions.

\section{Presentation of the basic material}

It should be noted that in contrast to economically developed countries where energy saving is an element of regional sustainable development policy, in Ukraine the question of energy efficiency of regions and increase of their efficiency is not a priority of regional policy, and certainly is not considered in the context of ensuring sustainable development of the regions. In this regard, the regions of Ukraine suffer from low energy efficiency and, consequently, excessive energy consumption, a high degree of dependence on external conventional energy sources, the prices, which in recent times are constantly growing, instability and opacity of the regulatory policy in the energy sector.

It should be noted that in the terms of today conditions the use of renewable energy sources is one of the most promising solutions to the growing problems of energy supply and sustainable development of the state in general and its regions in particular.

Table 1

Renewable energy and energy efficiency of regions of Ukraine, 2015

\begin{tabular}{|c|c|c|c|c|c|c|c|}
\hline \multirow[t]{2}{*}{ Name of the region } & \multirow[t]{2}{*}{ 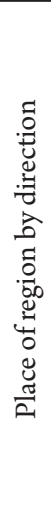 } & \multicolumn{2}{|c|}{$\begin{array}{l}\text { The share of equipment of } \\
\text { apartment houses by house- } \\
\text { to-metering devices of thermal } \\
\text { energy, the percentage of the } \\
\text { total number of apartment } \\
\text { buildings that are subject of } \\
\text { equipment }\end{array}$} & \multicolumn{2}{|c|}{$\begin{array}{l}\text { The share of the total capacity of } \\
\text { boiler houses on alternative fuels } \\
\text { in the region, the percentage } \\
\text { of the total capacity of boiler } \\
\text { houses of the region }\end{array}$} & \multicolumn{2}{|c|}{$\begin{array}{l}\text { The percentage of households that } \\
\text { have entered into loan agreements } \\
\text { in the framework of mechanisms } \\
\text { to support energy efficiency } \\
\text { measures in the residential sector } \\
\text { at the expense of the state budget } \\
\text { (including the co-financing from } \\
\text { the local budgets), the percentage of } \\
\text { the total number of households in } \\
\text { the region }\end{array}$} \\
\hline & & $\%$ & $\begin{array}{l}\text { place } \\
\text { according to } \\
\text { evaluation }\end{array}$ & $\%$ & $\begin{array}{c}\text { place } \\
\text { according to } \\
\text { evaluation }\end{array}$ & $\%$ & $\begin{array}{l}\text { place according } \\
\text { to evaluation }\end{array}$ \\
\hline Vinnytsia & 3 & 65,3 & 2 & 3,7 & 6 & 0,5 & $8-13$ \\
\hline Volyn & 8 & 25,9 & 17 & 5,0 & 4 & 0,5 & $8-13$ \\
\hline Dnipropetrovsk & 20 & 40,6 & 12 & 0,8 & $13-14$ & 0,3 & $17-25$ \\
\hline Donetsk & 22 & 36,5 & 13 & 0,7 & $15-18$ & 0,3 & $17-25$ \\
\hline Zhytomyr & 14 & 20,3 & 22 & 0,9 & 12 & 0,7 & $2-4$ \\
\hline Zakarpattia & 19 & - & - & 0,7 & $15-18$ & 0,6 & $5-7$ \\
\hline Zaporizhzhia & 10 & 56,8 & 3 & 1,6 & 10 & 0,3 & $17-25$ \\
\hline Ivano-Frankivsk & 2 & 42,6 & 9 & 6,3 & 2 & 0,5 & $8-13$ \\
\hline Kyiv & 13 & & 14 & 3,1 & 7 & 0,3 & $17-25$ \\
\hline Kirovohrad & 7 & 42,1 & 10 & $4-9$ & 5 & 0,4 & $14-16$ \\
\hline Luhansk & 25 & 14,5 & 23 & 0,03 & $23-25$ & 0,3 & $17-25$ \\
\hline Lviv & 6 & 68,6 & 1 & 0,4 & 20 & 0,7 & $2-4$ \\
\hline Mykolaiv & 12 & 50,5 & 7 & 1,9 & 9 & 0,3 & $17-25$ \\
\hline Odesa & 24 & 24,0 & 18 & 0,1 & 21 & 0,3 & $17-25$ \\
\hline Poltava & 23 & 22,1 & 21 & 0,7 & $15-18$ & 0,4 & $14-16$ \\
\hline Rivne & 4 & 33,1 & 16 & 5,1 & 3 & 0,7 & $2-4$ \\
\hline Sumy & 5 & 40,7 & 11 & 0,03 & $23-25$ & 1,1 & 1 \\
\hline Ternopil & 15 & 5,8 & 24 & 3,0 & 8 & 0,6 & $5-7$ \\
\hline Kharkiv & 1 & 55,4 & 5 & 6,8 & 1 & 0,3 & $17-25$ \\
\hline Kherson & 16 & 48,7 & 8 & 0,04 & 22 & 0,4 & $14-16$ \\
\hline Khmelnytskyi & 9 & 56,5 & 4 & 0,6 & 19 & 0,5 & $8-13$ \\
\hline Cherkasy & 21 & 23,9 & $19-20$ & 0,8 & $13-14$ & 0,5 & $8-13$ \\
\hline Chernivtsi & 17 & 23,9 & $19-20$ & 0,7 & $15-18$ & 0,6 & $5-7$ \\
\hline Chernihiv & 18 & 35,4 & 15 & 0,03 & $23-25$ & 0,5 & $8-13$ \\
\hline city of Kyiv & 11 & 55,2 & 6 & 1,5 & 11 & 0,3 & $17-25$ \\
\hline
\end{tabular}


The primary element of the research is to assess the potential of using alternative sources as the state as a whole and in individual regions, which are characterized by respective capabilities. One of the tools of the analysis of efficiency is a rating, which is based on the methodology of the International Energy Agency (IEA) and determines the efficiency of energy use in each region of Ukraine, concerning the structure of the regional economy. The energy consumption of the region is divided into the final consumption of energy in 10 sectors of the processing industry, agriculture, mining industry, construction, services sector and housing, for each of which is an indicator of efficiency.

Evaluation is performed based on the comparison of the final energy consumption of regions with similar indicators of the countries of the European Union (EU), which are used as a conditional model of energy efficiency for Ukraine. The gap between the energy consumption of the region and the benchmark determines the potential of each region for energy efficiency: what it is, the lower the energy efficiency of the region, the greater the amount of energy you can save on the condition of approximation to EU standards. The rating also gives an answer to the question on what factors changes in energy consumption depend. In particular, it determines how the energy consumption of the region is affected by changes in energy intensity, decline/increase in business activity and structural changes in the economy of the region. In 2015, the energy efficiency rating of regions of Ukraine looked like this (Table 1).

Many large corporations consistently develop and support energy efficiency, encourage the discussion and dissemination of modern practices in society, cooperate with public organizations. One of the main initiatives in this direction is the annual observance of the energy efficiency Rating of Ukrainian regions, Ukrainian Energy Index, the purpose of which is to determine how energy efficient is our country and its separate regions, and what potential we have to increase the level of energy efficiency. In general, alternative energy sources, renewable energy sources, which include: solar, geothermal, wind, hydropower, biomass energy, gas from organic waste, gas of sewage stations, biogas and secondary energy resources, which include blast furnace and coke gases, methane gas degasification of coal deposits, transformation of waste energy potential of technological processes are widely used in modern society in parallel with the increase in the price of oil and gas increases and the volume of investment in renewable energy (Table 2).

At the present stage of development of world oil market, prices are formed on exchanges based on supply and demand, as well as under the influence of factors that shape the supply and demand. The demand for oil is determined primarily by the growth rate of the world economy, as well as a number of other factors, including
Table 2

Global investment in renewable energy

\begin{tabular}{|c|c|c|c|c|}
\hline Years & $\begin{array}{c}\text { The average } \\
\text { oil price, } \\
\$ / \text { bar }\end{array}$ & $\begin{array}{c}\text { Investment } \\
\text { in renewable } \\
\text { energy, billion } \\
\text { US dollars }\end{array}$ & $\begin{array}{c}\text { Growth of } \\
\text { prise rates, } \\
\%\end{array}$ & $\begin{array}{c}\text { The growth } \\
\text { rate of } \\
\text { investment, } \\
\%\end{array}$ \\
\hline 2004 & 35 & 62 & 0 & \\
\hline 2005 & 52 & 88 & 48,57 & 41,94 \\
\hline 2006 & 63 & 130 & 21,15 & 47,73 \\
\hline 2007 & 57 & 183 & $-9,52$ & 40,77 \\
\hline 2008 & 133 & 205 & 133,33 & 12,02 \\
\hline 2009 & 45 & 207 & $-66,17$ & 0,98 \\
\hline 2010 & 89 & 276 & 97,78 & 33,33 \\
\hline 2011 & 117 & 317 & 31,46 & 14,86 \\
\hline 2012 & 120 & 291 & 2,56 & $-8,20$ \\
\hline 2013 & 110 & 269 & $-8,33$ & $-7,56$ \\
\hline 2014 & 87 & 315 & $-20,91$ & 17,10 \\
\hline 2015 & 65 & 349 & $-25,29$ & 10,79 \\
\hline 2016 & 53 & 387 & $-18,46$ & 10,89 \\
\hline
\end{tabular}

structural characteristics of the demand for oil, energy and oil capacity of economy, climatic (weather) conditions, the level of efficiency of energy-consuming technologies and the relative competitiveness of other fuels. The supply of oil on the world market is determined by world demand, geological, and technological factors, structural characteristics of world production and exports of oil, politics of oil-producing states, as well as a number of other factors, including factors of a random nature, such as military action in the regions of oil production.

Common power supply problems, certain issues that affect them, are under constant attention of world international organizations, first, and foremost energy ones. They are the International Energy Agency (IEA), World Energy Council (WEC), International Atomic Energy Agency (IAEA), Statistical Department of the European Commission (EUROSTAT), CIS Electric Power Council, and others.

The solar energy sector in alternative energy is one of the rapidly growing. This type of energy is available in almost every corner of our planet. It attracts investors for its sustainability, without prejudice to the biosphere can be used about 3\% of the solar flux arriving at the Earth. This will give the energy capacity of 1000 billion $\mathrm{kWh}$, 100 times the current capacity of energy production in the world. Today about $90 \%$ of the world's solar energy market is based on silicon technology. The benefits of manufacturing solar panels (PV modules) using silicon technology are sufficient availability of silicon in nature, its chemical stability, and the absence of any toxic effects on people and the environment. With a combination of a photomodulation solar power plant whose capacity depends on the number of mounted solar panels. Such solar modules can be placed on the roofs and facades of buildings that will meet household needs for electricity. One of the world leaders in the use of solar energy is China. 
The annual technically achievable energy potential of solar energy in Ukraine is equivalent to 6 million tons of standard fuel; its use would allow replacing about 5 billion $\mathrm{m} 3$ of natural gas. Today, the country established its own production of highly efficient silicon solar cells with efficiency up to $20 \%$. In Ukraine, five solar power plants are commissioned. One of them, up to date, the largest in the CIS, 7.5 MW in the village of Dzherelne (Crimea) - it was designed and built by an Austrian company ActivSolar. In the Crimea, solar energy is most prevalent. In 2011, there were commissioned a photovoltaic solar power station "Perove", which is located in the area more than 200 of gait produces $105,56 \mathrm{MW}$ of electricity. At that time, the plant became the largest in the world among its own kind. In general, in mainland Ukraine, there are several dozens of solar power plants capacity from 1 to $15 \mathrm{MW}$, and more than a dozen SES have a capacity from 20 to $120 \mathrm{MW}$ (some under construction). Thanks to a special "green tariff", which is valid since 2011, solar energy has become a lucrative business that has attracted foreign investors. According to statistics, the volume of commissioning of new solar power plants in 2013 almost doubled compared to 2012.

Wind energy is the alternative energy industry, specializing in the conversion of kinetic wind energy into electrical energy. Now, most of the world is trying to take advantage of this kind of energy, looking for the most affordable and economical ways of wind use. For example, in Germany, Austria, and Switzerland wind turbines are already used. With their help, individual settlements are fed. In Germany, 7\% of all energy that is consumed is produced using renewable energy sources, with $4 \%$ accounted for by wind generators. One reason for this is the purposeful state policy on the development of alternative energy. So, a few years ago in this country, a law was passed, which aims at the expansion of alternative energy. It suggests that all operators, for example, solar panels receive from the government compensation of 50-52 cents per produced kilowatt-hour of electricity. For other installations and wind generators and turbines - there are lower tariffs.

Ukraine has areas with constant strong winds; making wind energy development has a rationale. Even despite the higher cost of wind energy (compared to traditional), the use of wind energy is economically feasible in the steppe (particularly coastal) and mountain regions (Mykolaiv, Kharkiv, Odesa, Luhansk, and Donetsk region, as well as the mountainous areas of the Carpathians and of the annexed Crimea). According to estimates, wind power could provide Ukraine with $15 \%$ of the total electricity requirements (Zavalion, 2013). As in the case of solar, wind power also has a "green tariff". Because of that, during 2013, the share of wind energy has actually doubled, despite the fact that wind energy from the point of view of "business" is less profitable than solar. It is worth noting that wind energy in Ukraine was developed and to the establishment of "green tariff". Therefore, in 1992, construction began on Donuzlavska wind power plant (Crimea), which now generates more than $17 \mathrm{MW}$ of electricity. Among other powerful wind power plants can be noted Botievska wind farm (Zaporizhia region) with a capacity of 200 MW, Novoayovska wind farm (Donetsk region) with a capacity of 79.3 MW (Kravchenko D.V.). Despite the rapid development of wind energy, its fate for energy barely crosses the mark of $1 \%$ of the total electricity generated in Ukraine. This figure is very small; however, it implicitly will grow. This will not only contribute to "green tariff" but also a constant rise in prices of mineral resources (namely fuel burning on thermal power station now provides more than a third of our electricity needs) (Yandulsky, 2013).

In the world is built a large number of hydropower plants that produce up to $5 \%$ of the total electricity, and in some countries, the share of electricity generated from hydropower is much higher. Brazil ranks third in the world after China and Canada on the installation of generating units and on the provision of the hydropower resources in second place is Russia, after China.

Hydropower in Ukraine began with the construction of the largest in Europe at the time of the Dnieper HPP 560 MW. In 2009, commissioned two small hydropower plants: Lotashovska Power Small HPP of $315 \mathrm{~kW}$ in the Cherkasy region and Yablunetska Small HPP capacity of $1000 \mathrm{~kW}$ in Chernivtsi region (Voronovsky, 2010). The potential of small hydropower in Ukraine has more than 63 thousand small rivers and watercourses with a total length of 135.8 thousand. The greatest potential of small rivers in Ukraine is concentrated in the Carpathian region (Shidlovsky AK, 2013, p. 301). Modern state of small hydropower in Ukraine is represented by 70 small hydro power plants, among them such relatively powerful stations as Gaivoronska, Tereble-Rykska, Steblivska, Korsun-Shevchenkivska, Ladyzhenska, and others; technical condition of existing HPPs is significantly or completely worn out main hydropower, hydraulic, and electrical equipment; the presence of faults in the waterfront buildings, which may cause emergency situations; increase of water intake for non-energy uses; silting of reservoirs; erosion of fasteners spillway and coastal areas of lower bays; small hydropower in Ukraine through its negligible share $(0.2$ per cent) in the total energy balance may not significantly affect the conditions of supply of the country. However, the exploitation of small hydropower plants produces about 250 million $\mathrm{kWh}$ hours of electricity per year, equivalent to annual savings of up to 75 thousand tons of scarce fossil fuels (Biofuels, 2016).

Bioenergy - energy sector based on the use of biofuel that is created using biomass. Biomass is a constant or a variable substance of animal or vegetable origin, subject to biodegradation, which occurs from the products and wastes of agricultural and forest production, and 
industrial production. The production of electricity and heat from solid biomass is carried out by combustion of solid fuel fired boilers with the steam of high pressure. This process is carried out by using biomass power plants. The annual growth of biomass in the world is estimated at 200 billion tons (in terms of dry substance), which is energetically equivalent to 80 billion tons of oil. One of the sources of biomass is a forest. In the processing of timber, there is 3-4 billion tons of waste, the energy equivalent of which is 1.1-1.2 billion tons of oil. World energy demand (11 billion tons) is only $12 \%$ of the energy of the annual world biomass growth. The proportion and amount of biomass used for energy declines, which can be explained by the relatively low calorific value of biomass due to its high content of water. Most noteworthy of conversion of biomass and organic waste for biogas, since in this case, in addition to fuel, produces a valuable organic fertilizer. In China, secondgeneration biofuels are very popular. Now scientists are working on the development of a new type of producing energy from algae. By 2020, China plans to produce up to 12 million tons of aviation biofuel a year. In the energy balance of China, renewable energy sources (sun, wind, and water) are $30 \%$. The European Union use not only energy resources from landfills, agricultural or timber production but also specifically grown energy crops growing. The most favourable energy crops for solid biofuel are willow and poplar. In Sweden and Denmark, for example, they are used in local heating systems for the combined production of heat and electrical energy.

REmap is an analytical approach to the evaluation of the differences between current national plans for renewable energy development, potential additional development opportunities for renewable energy until 2030 and the SE4All goal of doubling the share of energy from renewable sources by 2030 on a global scale. In June 2014 in the framework of REmap 2030, 26 countries are evaluated: Australia, Brazil, Canada, China, Denmark, Ecuador, France, Germany, India, Indonesia, Italy, Japan, Malaysia, Mexico, Morocco, Nigeria, Russia, Saudi Arabia, South Africa, South Korea, Tonga, Turkey, Ukraine, United Arab Emirates, United Kingdom, and United States of America (Statystka, 2015).

An important element of policy implementation in the field of energy saving and use of alternative sources is the introduction of financial, organizational and economic activities that give the opportunity to implement the principles of sustainable development in public administration, and decentralization and local governments.

As noted by Denisyuk S.P. (Denisyuk, 2013) in the management, the defining are such policies in the field of energy efficiency:

- pricing mechanisms (variable tariffs where a higher level of consumption have a higher unit cost);

- mechanisms of regulation and control (compulsory activities such as energy audit and control of energy consumption; minimum energy standards, targets to reduce energy consumption, the liabilities of private companies for investment in energy efficiency);

- financial measures and fiscal incentives (grants, subsidies and tax incentives for the investment in energy efficiency; direct procurement of goods and services for energy efficiency);

- mechanisms of development and transformation of the market (media companies, the inclusion of energy efficiency in school curricula; labelling of appliances and certification of buildings);

- technological development (development and demonstration of energy efficiency technologies);

- business development and capacity building (creation of energy service companies (ESCOs); the curriculum; the development of the industry of energy efficiency); financial recovery (revolving funds for energy efficiency investments; funds for training projects; funds raised for financing).

\section{Conclusions}

In Ukraine, there are a sufficient number of economic, technological, and social needs in the use of alternative energy sources. However, there is a lack of funding and the imperfection of the legal base in this issue on the one hand, and a number of laws and acts, the direction of which is the promotion and implementation of the country's potential in energy efficiency, energy independence, and energy security of the country as a whole. The question assumes high relevance in our country, however, is not relegated to the background in developed countries, so the EU itself has a high level of adoption and use of renewable energy sources that allows Ukraine as a state that wants to meet requirements of the EU quite easy to obtain and learn from the experience in this matter, which will have a positive impact on the economy of the state, and to a certain extent, everyone in Ukraine.

\section{References:}

Biofuels [Electronic resource]. - Access mode: http://energetyka.com.ua/biotoplivo/532-biopalyvo

Denisyuk S.P. (2013). Features of energy efficiency policy and priorities of Ukraine. Power engineering: economics, technology, ecology, 3: 7-19.

During the year in the world in alternative energy investments of $\$ 270$ billion [Electronic resource]. - Access mode: http:// eircenter.com/news/za-rik-v-alternativnu-energetiku-investovano-\$270-mlrd/

Energy: past, present and future. [Electronic resource]. - Access mode: http://energetika.in.ua/ru/books/book-1/ part-2/section-8/107 
Kravchenko D.V. Current state and prospects of development of wind energy in [Electronic resource]. - Access mode: http://www.confcontact.com/2009ip/kravch.htm

Ratner V.M. (2013). Solar power plant-facility of power system. Thermal solar systems, the potential of the South of Ukraine (Odessa, Mykolaiv, Kherson regions). Electric networks and systems, 3: 40-48.

The prospects of renewable energy in Ukraine until 2030. [Electronic resource]. - Access mode: http://saee.gov.ua/sites/default/files/UKR\%20IRENA\% 20REMAP\%2 0_\%202015.pdf

Shidlovsky A.K. (2013). Energy efficiency and renewable sources of energy, 559.

Shishkina I.O. (2013). Alternative energy sources the world market: current status and prospects. Economy of industry, 1(2): 103-109.

Voronovsky G.K. (2010). Energy of the world and Ukraine. Facts and figures, 404.

Yandulsky O.S. (2013). Features of the analysis of modes of electric power systems with wind power plants. The world of technology and technology, 6:24-25.

Zavalion Yu. (2013). Ukraine is the leader among the CIS countries in implementation of wind turbines. Ecology of the enterprise, 10: 58-64.

Wikipedia [Electronic resource]. - Access mode: //https://ru.wikipedia.org/wiki/

\section{Елена ЛЮТАК, Лариса САВОШ, Елена БАУЛА}

\section{ОСОБЕННОСТИ ИСПОЛЬЗОВАНИЯ АЛЬТЕРНАТИВНЫХ ИСТОЧНИКОВ ЭНЕРГОРЕСУРСОВ}

\section{В УКРАИНЕ И МИРЕ}

Аннотация. Целью работы является рассмотрение теоретико-прикладных основ использования альтернативных источников энергоресурсов в Украине и мире, исследования теоретических основ и специфики использования существующих источников альтернативной энергетики в условиях глобализации, мировая практика использования альтернативных источников энергоресурсов, освещены особенности использования альтернативных источников энергии в Украине в современных условиях. Особое внимание сосредоточено на анализе энергоэффективности регионов Украины и факторов, ее определяющих, а также исследованы общий тренд по конъюнктуры на рынке нефти и объемов инвестиций в возобновляемую энергетику. Методика. Исследование основано на показателях возобновляемой энергетики и энергоэффективности регионов Украины в 2015 году и включение показателей средняя цена нефти, инвестиции в возобновляемые источников по энергии, темпы роста цены, темпы роста инвестиций в 2004-2016 гг. Всего на материковые Украине насчитывается несколько десятков солнечных электростанций мощностью от 1 до 15 MBт, а больше дюжины СЭС имеют мощность от 20 до 120 МВт (некоторые только строятся). Благодаря специальному «зеленому тарифу», который действует с 2011 года, солнечная энергетика стала прибыльным бизнесом привлекло иностранных инвесторов. По статистике, объем ввода в строй новых солнечных электростанций в 2013 году почти удвоился по сравнению с 2012-ым. Результаты определили, что важным элементом реализации политики в сфере энергосбережения и использования альтернативных источников является внедрение финансовых, организационных и экономических мер, которые позволяют внедрять принципы устойчивого развития в государственном управлении, а в условиях децентрализации и органами местного самоуправления. В управлении определяющими являются такие меры политики в области энергоэффективности: механизмы ценообразования; механизмы регулирования и контроля; финансовые меры и налоговые стимулы; механизмы развития и преобразования рынка; технологическое развитие; коммерческое развитие и создание потенциала (создание энергосервисных компаний (ЭСКО), учебные программы, развитие индустрии энергоэффективности) финансовое восстановления. 